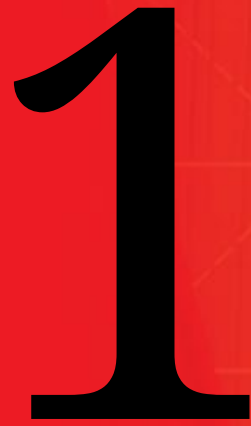

\title{
WHAT'S THE PLAN?
}


WITH GREAT FANFARE BUT FEW SURPRISES, the Chinese government launched its Thirteenth FiveYear Plan at the March 2016 annual plenary session of the National People's Congress, China's national parliament. Since 1953, five-year plans, a Sovietstyle planning tool, have laid out China's major economic development objectives, as well as setting out the indicators of social and cultural progress that define the nation's priorities for development. The 2016 plan was two years in the making. In line with the new look of Chinese propaganda, it was accompanied by a social media storm aimed at both domestic and international audiences. This included an animated musical video on YouTube featuring two Americans proudly making fun of their accent in Chinese while elaborating on the goals of the plan in song. ${ }^{1}$ As always, China used the plan to tell a new story about itself - but this time with popular appeal.

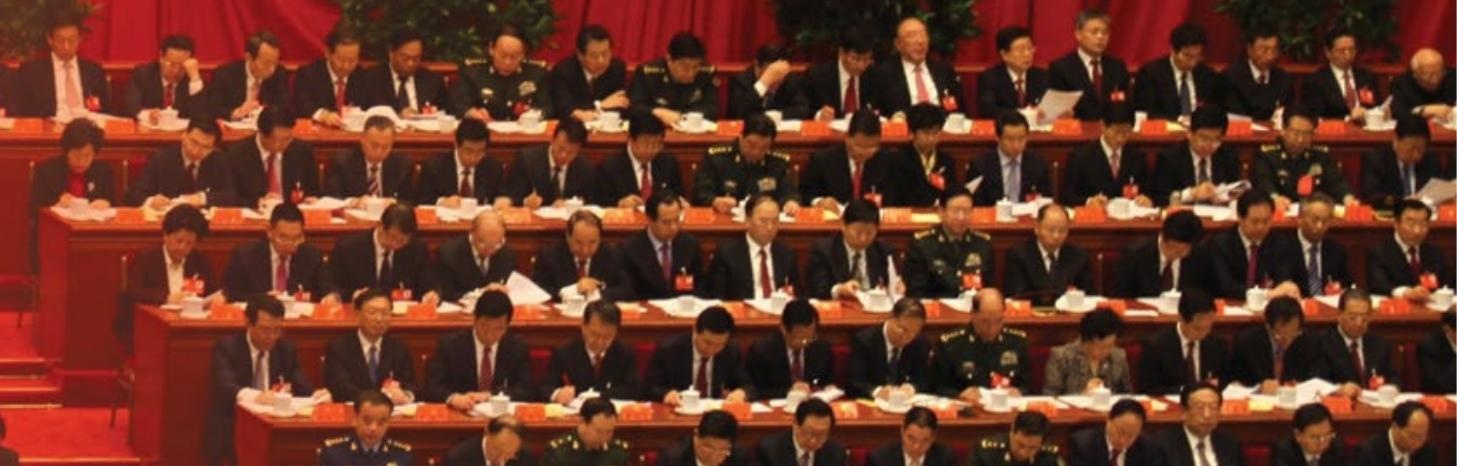




\section{Does China Need a Five-Year Plan?}

Comprehensive, relentless planning is at the core of a Soviet-style socialist economy. It took the USSR a decade after the October Revolution to launch its first Five-Year Plan - a three-volume, 17,000-page document in which the central planning agency, Gosplan, elaborated all of its economic targets for the period between 1928 and 1933. It aimed to boost industrialisation to the point where the USSR would be able to compete with - and eventually fight - the West. This Plan produced results similar to that of China's first plan: the rapid collectivisation of agriculture,

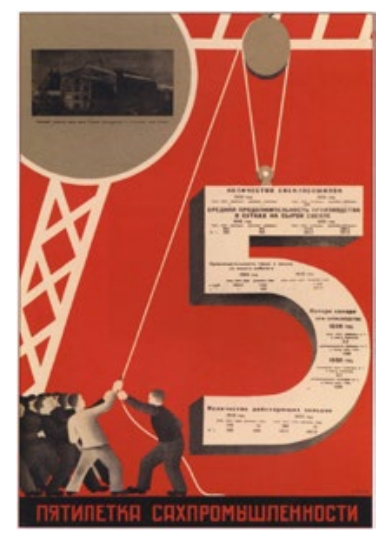

Soviet five-year plan propaganda Photo: crisissome.blogspot.com.au nationalisation of all industry, and even the great famine that hit Russia at the end in 1932-1933, which, like China's famine of 1958-1962, was partly as a consequence of the overzealous application of agricultural and other targets by local cadres.

Five years was considered long enough to allow for the construction of factories and other infrastructure, and to average out good and bad harvests in the agricultural cycle. At the same time, it was not so long as to endanger the state's capacity to steer the economy through unexpected turbulence, adjust targets as necessary, and introduce corrections to the structural aspects of economic development - in other words, to adapt flexibly to changing circumstances. Despite the shortening of production cycles in more recent times, the ancient Roman concept of lustrum (the five years between censuses) still holds its ground today as the ideal planning period. Mikhail Gorbachev oversaw the preparation of the USSR's Twelfth and Thirteenth Five-Year Plans, although the latter was rendered irrelevant by the demise of the USSR in 1991. 
Non-socialist countries have also adopted such plans, particularly where economic development is taken to be crucial to nation building: India is currently seeing through its Twelfth Five-Year Plan while Turkey has enacted ten five-year plans so far. Even Adolf Hitler decided to emulate what he considered the Soviets' 'grand plan' and launched his very own Four-Year Plan in 1936, to prepare Germany for war.

China shows no sign of abandoning the practice of five-year plans. In recent years, however, the nature of the plans has changed along with China's evolving economy. Earlier plans provided rigid targets for a developing economy dominated by agriculture and industry - one which, with the nationalisation of industry in 1956 and the collectivisation of the agriculture around the same time, had become the responsibility of the state alone. With the end of the Maoist era, the expansion of the market economy, the growth of consumer and services sectors, and the opening

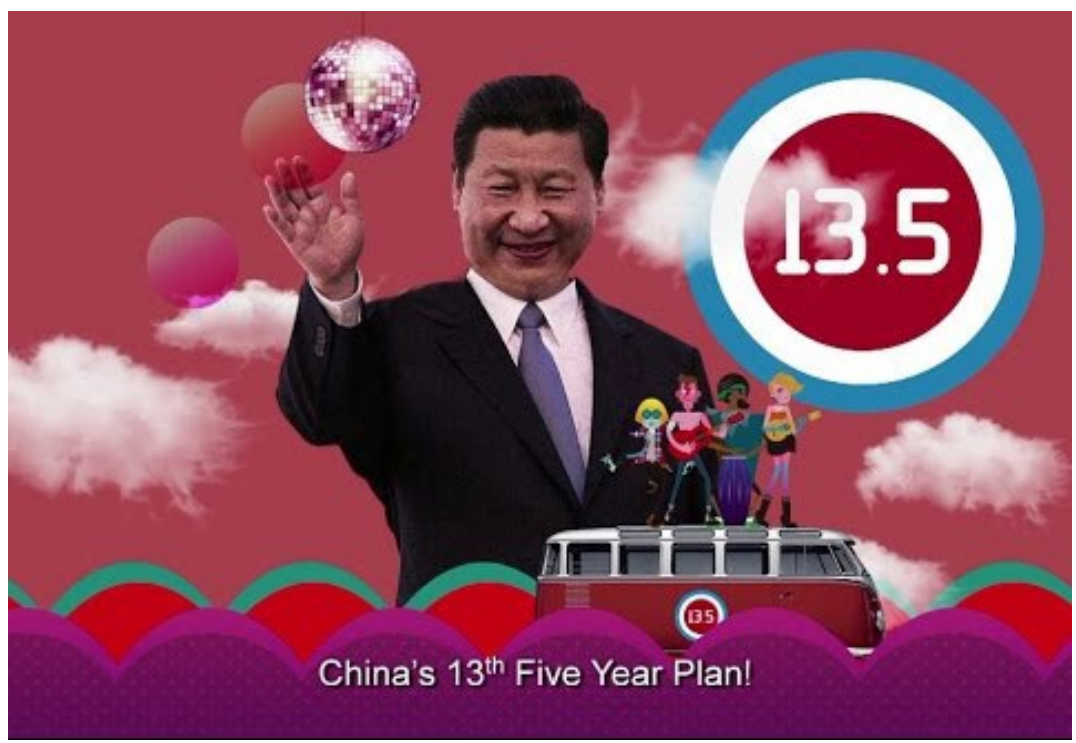

A still from the animated musical video explaining the Thirteenth Five-Year Plan Photo: YouTube 
of Chinese stock markets, plans necessarily became increasingly complex and long term in their conception. The Fifth Five-Year Plan (1976-1980) and the Sixth Five-Year Plan (1981-1985), for example, were bundled into one ten-year development plan; these were also

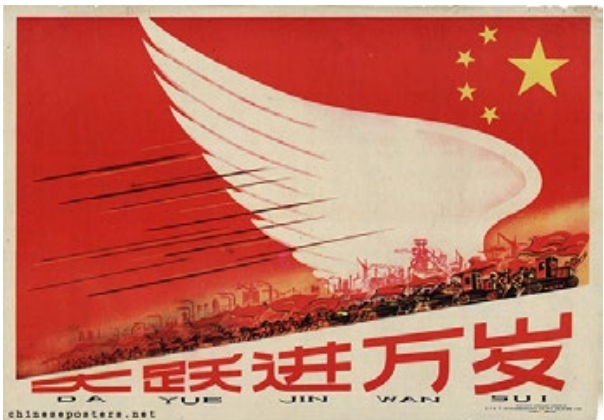

Long live the Great Leap Forward

Photo: chineseposters.net the first to acknowledge that the over-ambitious (and ideologically motivated) production targets set during the Great Leap Forward 大跃进 (1958) and the Cultural Revolution 文化大革命 (1966-1976) were unachievable.

In more recent times, five-year plans have reflected how the greater role of the market in the national economy has made it harder and less crucial for the government to set hard targets. Since 2011, moreover, the term guihua 规划 has unceremoniously replaced the traditional word for 'plan' jihua 计划. While both translate as planning, the original expression implied the setting of targets ( $j i$ also means count, compute, number), while the latter indicates the desire to guide (gui means regulate) and is used to indicate a more strategic and co-ordinated art of planning (as in urban planning). Yet under either name, the continued, regular recurrence of the five-year plan also reflects the lasting need for a scientific and rational way to govern or control the economy. Today, five-year plans are no longer about setting unachievable grain or steel output targets of the sort that contributed to the Great Leap Forward's economic waste and led eventually to a nationwide famine. They are, rather, about aspirational targets: 'innovation', for example.

As it does with all of its major, central documents, the Party-state has woven a powerful and unequivocal narrative through the pages of this 
latest Plan. The narrative today is of a modern, green, innovative nation where increasingly well-educated young Chinese are going to transform the country from a 'copycat nation' into a well-funded and advanced hub for the production of the world's most important commodity: original ideas. This narrative suggests that China is leaving behind the kind of labour-intensive self-exploitation that produced its first industrial boom. Instead, it is devoting itself to colonising a much more rewarding section of the global economy, where some of its firms are already playing a primary role (for example in e-commerce and wind energy production, where China leads the world). The innovation drive central to the new Plan could, according to McKinsey \& Company, contribute up to one quarter of China's GDP growth between now and 2025. By that time, China may, have 'evolved from an "innovation sponge", absorbing and adapting existing technology and knowledge from around the world, into a global innovation leader'. ${ }^{2}$

\section{What is Planning?}

Originally, the State Planning Commission 国家计划委员会 and later the State Development Planning Commission 国家发展和计划委员会 were responsible for drafting the Plan. Since 2003, the new National Development and Reform Commission (NDRC) 国家发展和改革委员会 is in charge of drafting the Plan, despite the fact that its name doesn't even include the word 'planning'.

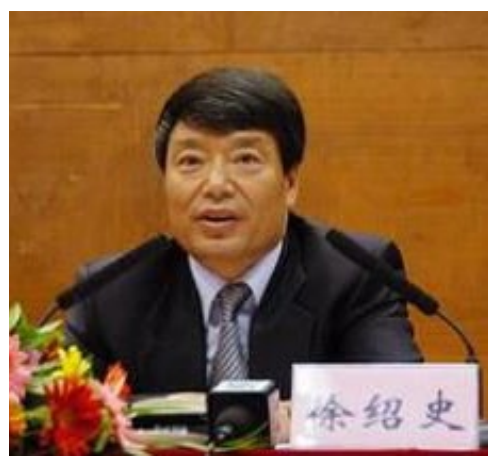

Xu Zhaoshi, incumbent Chairman of the NDRC Photo: baike.com

The NDRC's army of researchers typically consults with academics and scientists for two years before drafting the national blueprint. It also 
THE THIRTEENTH FIVE-YEAR PLAN, by Lorand Laskai

On 15 March, China's National People's Congress adopted the country's Thirteenth Five-Year Plan 十三五规划纲要. It focuses on innovation, structural reform, environmental protection, and transitioning away from an investment-dependent growth model. Coming at a time of economic restructuring and slowing economic growth, the Plan presents the government's vision for China's 'new normal' 新状态 - which is of China as a world leader in innovation, with a 'modestly prosperous'
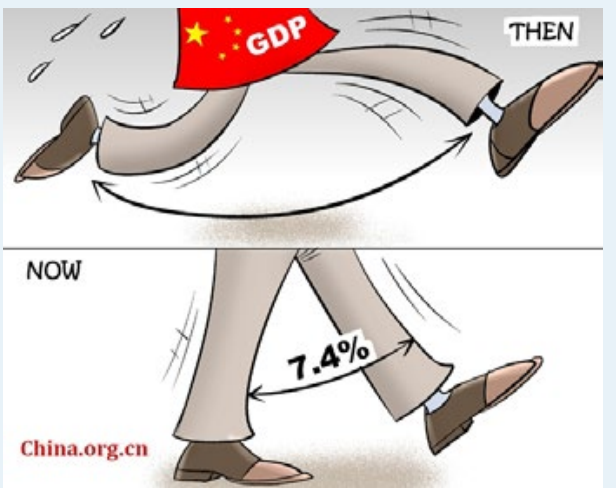

China's 'new normal'

Photo: china.org.cn society 小康社会, and a consumption-driven economy.

The Thirteenth Five-Year Plan, which covers the period from 2016-2020, sets five major objectives:

1. Technological and informatisation: The Plan sets the most ambitious targets for technological development to date. Innovation takes first place in the Plan and takes up a whopping thirty-eight pages. The Plan lays out nine major initiatives, including 'Sci-Tech Innovation 2030 - Megaprojects' (which prioritises the development of certain technologies like new aviation engines and gas turbines, robotics in the field of manufacturing, and the development of so-called 'advanced materials'), 'Made in China 2025' (focusing on upgrading manufacturing technology), and 'Internet Plus' (extending the use of the Internet in industry). Together these projects will attempt to make China a global innovation leader in the fields of smart manufacturing, big data, quantum telecommunications, and robotics. Notably, the Plan marks the return of 'indigenous innovation' 自主创新 (used six times in the Plan), an expression that had been replaced by 'innovation-driven development' 创新驱动 发展 in 2012 to assuage fears of foreign businesses that they would be left out of China's innovation drive. ${ }^{4}$ While the Plan has a long list of priority technologies the Chinese government hopes to develop, these are expressed in broad, or vague terms.

2. Environment: Environment-related targets account for half of all mandatory targets. Together, they add up to the boldest outline for environment protection and tackling pollution in a Chinese five-year plan to date. Most notably, the Plan places quotas for cleaning-up waterways (raising the number of waterways suitable for drinking and fishing to seventy percent) and reducing PM2.5 nationwide. The Plan also sets targets for increasing 
the share of non-fossil fuel-based energy to fifteen percent of total supply (up from 11.4 percent).

3. A mid-high target for economic growth: Despite rising debt, a slowing economy, and overcapacity in many industries - and early drafts of the Plan that had scrapped growth targets altogether - economic growth remains an important priority, reflected in the Plan's growth target of 6.5 percent. The Plan acknowledges that achieving 6.5 percent growth will require tapping into new engines of growth and efficiency. ${ }^{5}$ It is also the first Plan to include an annual target for labour productivity, which is to increase by 6.6 percent per year.

4. Institutional reform: One way in which the Plan will attempt to unleash greater productivity is through expanding market-oriented reform. This includes reforming interest rates and the securities market in favour of the free market, simplifying regulatory codes, easing access to credit, and so on. Unsurprisingly, the Plan outlines a major push to reform state-owned enterprises (SOEs), a centrepiece of Xi's economic reform as SOE debt and the enterprises' collective burden on the economy spirals out of control. Meaningful reform requires making SOEs more self-sufficient and responsive to market forces. Many experts doubt Beijing will be successful, because of the political complexity of this issue, which relates to longstanding ideological assumptions about the structure of the Chinese economy post-1949.

5. Poverty reduction: One of the few non-environment related mandatory quotas in the Plan is for poverty reduction. Building on the momentum of the Twelfth Five-Year Plan the government intends to raise 55.75 million people out of poverty by 2020 . The Chinese government defines rural poverty as living on less than 2,300 renminbi a year (or 6.3 renminbi per day). That is still less than the World's Bank's global poverty standard of US $\$ 1.25$ a day. ${ }^{6}$

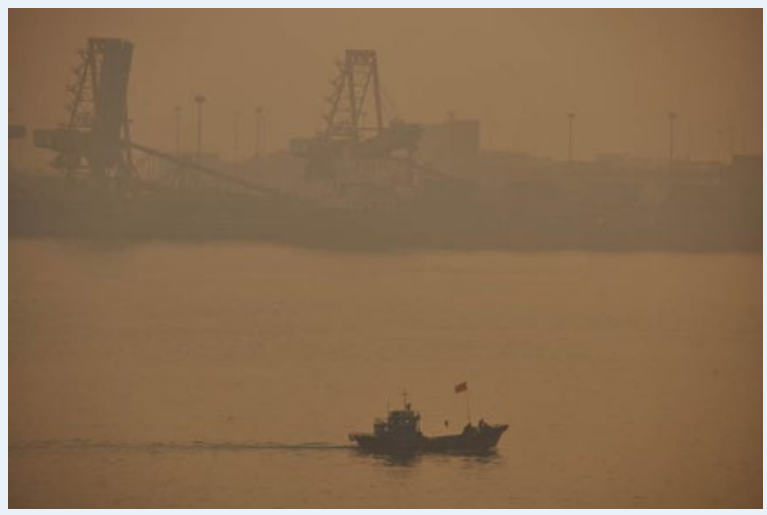




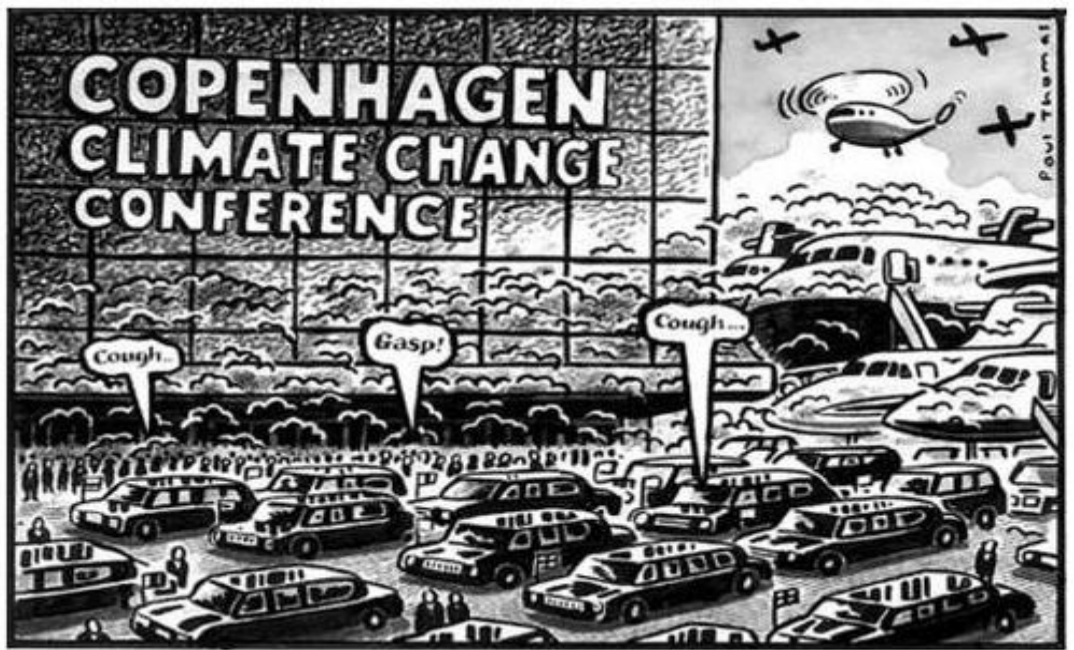

Copenhagen, 2009: United Nations Climate Change Conference

Image: Paul Thomas

solicits comments from the public, including through a forum on WeChat. While the capacity of individual citizens to influence the process is minuscule, the consultation allows the government to gather important information about public attitudes.

Today, state-owned enterprises (SOEs) produce around twenty-five percent of China's GDP. Most of the investment in China's economy comes from independent or semi-independent players and overseas investment, making it dependent on and responsive to market conditions in China and abroad. This raises the question: What is the point of central economic planning? Part of the answer lies in the fact that today, the stress is not on production targets but priorities for state investment. Recent plans have included both compulsory and aspirational targets and suggested ways in which they can be achieved.

The Thirteenth Plan, for example, commits to a greener China, with many of its thirty-three listed objectives relating to environmental protection and controls (see Information Window 'The Thirteenth Five-Year Plan', pp.8-9). The production of energy, which is the subject of a specific sub-plan, commits to a reduction of carbon dioxide emissions by a full forty-eight percent by 2020 from its 2005 figures — higher than the Copenhagen pledge - which would put China at the forefront of moves towards a low-carbon global economy. 
Despite the ongoing rise of China's private economy, the state is still in a privileged position to activate economic levers. Not only does it exercise direct control over one quarter of the nation's economic output, but it also has the power to allocate and regulate important assets such as land. The state owns all land in China, and it also exercises significant control over the financial markets through ownership of the four major banks. The remaining SOEs are quasi-monopolistic companies with almost unlimited reach into such crucial sectors as energy, transport, and infrastructure building. It is wrong to think that just because the private economy has outgrown the public sector, the state has lost or abandoned control over the economy.

The state still also directly controls education, and funds most academic and scientific research. Through these means it is increasingly betting on the creation of an ideas- and innovation-based economy. Investment in research and development (R\&D) has grown steadily, even if there is not yet a concomitant increase in high-quality patents. A recent article in the journal Nature ${ }^{7}$ showed that despite Chinese investment in R\&D already reaching two percent of GDP (higher than that of the European Union and behind only the US), only five percent of that investment goes to basic science, compared to experimental and applied research. Also, while the total number of researchers in China surpasses that of the US and is second only to the total of the twenty-eight EU countries, in per capita terms China still has only two researchers per thousand people, versus eight in the US. Its scientific publications, while gaining influence in the last decade, are still under the world average in terms of impact (measured in the frequency of citations of scientific articles in a particular year).

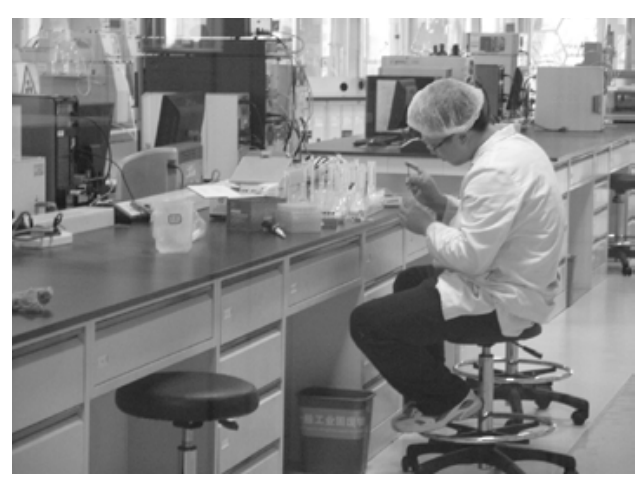

Chinese investment in R\&D has reached two percent of GDP Photo: Cory M. Grenier, Flickr 
Since the late 1990s, the government has committed to building 'world-class universities'. Much of the public funding for universities and tertiary-sector research has gone to a small group of elite schools that lobbied the government from the start. The investment paid off: in 2016, three of the best-funded Chinese universities (Tsinghua, Peking, and Fudan) entered the top fifty of the influential QS World University Rankings.

While the latest Five-Year Plan promises universities greater autonomy and internationalisation, it also allows the government to prioritise scientific disciplines or institutions in parts of the country that struggle to produce, retain, and attract academic talent, such as some of the central and western provinces. But a top-down approach to funding has proven less efficient than innovation that comes from the grassroots. The risk remains that where a notoriously inefficient and predatory bureaucratic system is in charge of directing research funding, the money will not go to the most interesting, effective or innovative projects.

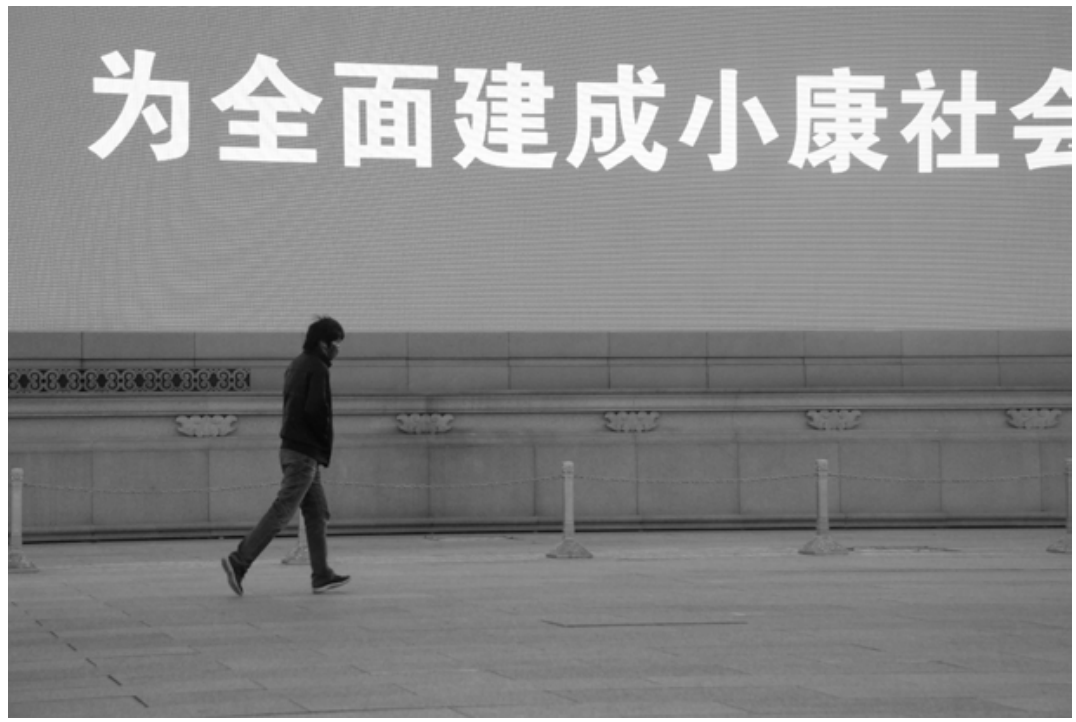

Electronic billboard, Tiananmen Square: 'Build a moderately wealthy society for all' Photo: Henry.LI, Flickr 
Insofar as the Thirteenth Five-Year Plan is a narrative, it would be tempting to dismiss it as just another expensive expression of a bankrupt ideology. Yet the Plan allows the CCP to present its role as ruling in the name of rationality and science. The emphasis in the Plan on building a 'moderately wealthy' society 小康 — an expression first used by Deng Xiaoping - and its explicit commitment to 'putting people first' 以人为 本 paints the image of a caring state rather than a powerful and infallible one, more interested in improving living conditions and the economy through rational means than hard targets: it is moving, you could say, from a command economy to an 'urge' economy.

The Plan also addresses rising collective anxiety over the state of the environment (now ahead of corruption in the ranking of public concerns). This anxiety affects the decisions of the growing middle classes, upon whose creativity and commitment the innovation economy greatly relies - will they, for example, send their children abroad or can they be persuaded to stay and invest in China's future? The Plan responds both to a structural demand of the Chinese economy, no longer able to choose between growth and environment, and to the demands for action by Chinese citizens.

By setting the country's economic growth target at (for post-Mao China) a relatively low 6.5 percent, the Plan signals the state's understanding that it needs to adopt a more 'coordinated' and 'inclusive' (both buzzwords of the new Plan) path to growth.

\section{The Best Laid Plans}

Economic planning is still about governing the future, but today's economic plan is telling a very different China story from plans of the past. In the latest Plan, a new 'scientific' language emerges to replace that of socialist ideology, with its declining credibility and reach. Whereas the plan for the Great Leap Forward, for example, demanded that China quadruple 
industrial and agricultural production so that the country would hasten towards a utopian future of communist abundance, the new Plan tells a more sober, but no less ambitious story of equality, autonomy, modernity, and globalisation, in which the state still plays the key role. Under the new Plan, poverty will be eliminated, the air cleaned, universities globalised, officialdom cleansed of corruption, farmers professionalised, rights respected, health guaranteed, social services improved, transport rationalised, access to education increased, cities expanded and made more liveable, and defence strengthened.

These are all goals that could figure proudly in the programs of both progressive and conservative political parties around the world. Yet they are also goals that require what may well be a painful transformation of China's political process in the direction of genuine accountability, so that the supervisor and the supervised, as well as the polluter and the pollution monitor, are no longer the same entity.

Even if the planned economy is no longer with us, planning in China is here to stay. But its nature is evolving - and the way in which it is changing, as much as its specific content, provide a once-a-lustrum insight into the continual reshaping of the China story itself. 


\section{TENSIONS FLARE IN TOP LEADERSHIP,}

by Matt Schrader

In 2016, previously rumoured tensions between the PRC President and CCP Chairman $X i$ Jinping 习近平 and Premier Li Keqiang 李 克强 burst into the open. This marks perhaps one of the most serious rifts at the top of the Chinese Party-state since Deng Xiaoping 邓小平 replaced Zhao Ziyang 赵紫

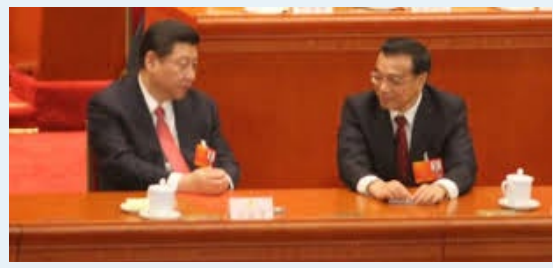

Xi Jinping (L) and Li Keqiang (R)

Photo: zh.wikipedia.org 阳 with Jiang Zemin 江泽民 and a cabal of Party elders during the Tiananmen crisis of 1989.

The two leaders have history. Both were mooted as candidates to succeed Hu Jintao 胡 锦涛 in the run up to his 2012 retirement. A US diplomatic cable released by Wikileaks ${ }^{8}$ recounts a 2007 conversation between $\mathrm{Xi}$ - then in charge of Zhejiang province - and thenUS ambassador Clark T. Randt, in which Xi goes out of his way to cast his province's situation in a positive light compared with Henan Province, where Li had only recently been governor. After Xi ascended to the posts of President and CCP Chairman, he quickly consolidated his hold over economic policy - an area that had been the domain of the premier under both Wen Jiabao 温家宝 and Zhu Rongji 朱F基.

Once in the job, Xi reconfigured high-level power structures to an unprecedented degree. Rumblings that $\mathrm{Li}$ and his camp were unhappy with some of the changes popped up sporadically in both Chinese and foreign media before 2016. ${ }^{9}$ Then, on 9 May 2016, a frontpage People's Daily essay by an 'authoritative person' - widely believed to be top Xi aide Liu He 刘鹤 - directly criticised the credit-heavy economic policies advanced by Li and his team, at length and in detail.

In post-1989 PRC elite politics, in which preserving the appearance of stability and consensus has been paramount, such overt airing of differences would normally constitute an unthinkable breach of protocol. But the Xi-Li feud appeared to escalate over the summer, culminating in Xi's 3 August public defenestration of the once-powerful Communist Youth League (CYL), which entailed both a halving of its budget and less powerful roles for its cadres and eighty-seven million members.

The CYL was also where Li began his political career in 1982, immediately upon graduation from Peking University. He spent the next sixteen years rising through its ranks, ${ }^{10}$ leaving the organisation in 1998 when he took up the post of governor of Henan Province. Former president Hu Jintao, his powerful former aide Ling Jihua 令计划 (who fell victim to a corruption investigation after his son's death at the wheel of a Ferrari in a weehours crash that also killed two college-age female passengers), and current Vice-President Li Yuanchao 李源潮 also spent large portions of their careers in the CYL. The League's role in cultivating young cadres has meant that its candidates tend to do disproportionately well in intra-Party elections - an important factor in cadre promotion.

Business as usual would see Li confirmed for an additional five-year term as premier at 2017's National Party Congress, and serve until his retirement in 2022. But speculation is rife that Li may be the first premier ousted from the role since Deng Xiaoping saw off Hua Guofeng 华国锋 in 1980. A major Party conclave in October indicated that rules around retirement age might be eased at the 2017 Party Congress, thus paving the way for sixty-nineyear-old Wang Qishan 王岐山, a key Xi ally and head of the formidable Central Commission for Discipline Inspection, to step into Li's role rather than step down into retirement. ${ }^{11}$ 
This text is taken from China Story Yearbook 2016: Control, edited by Jane Golley, Linda Jaivin and Luigi Tomba, published 2017 by ANU Press, The Australian National University, Canberra, Australia. 